\title{
Dispersion and abundance of Antarctic krill in the vicinity of Elephant Island in the 1992 austral summer
}

\author{
Roger P. Hewitt ${ }^{1}$, David A. Demer ${ }^{2, *}$ \\ ${ }^{1}$ Southwest Fisheries Science Center, La Jolla, California 92038, USA \\ ${ }^{2}$ Scripps Institution of Oceanography, La Jolla, California 92093, USA
}

\begin{abstract}
Antarctic krill Euphausia superba distribution and abundance were estimated from 4 acoustic surveys conducted in the vicinity of Elephant Island, Antarctica, from mid-January to midMarch 1992. The first and last surveys covered a 105 by $105 \mathrm{n}$ mile study area centered on Elephant Island; the second and third surveys covered a 60 by $35 \mathrm{n}$ mile area immediately north of Elephant Island. During the first survey, krill were distributed in a wide band extending along the north side of Elephant Island and wrapping around the western end; biomass was estimated to be 2.2 million metric tons ( $t$ ). During the second survey, the highest densities of krill were over the shelf extending to the northwest from Elephant Island and including the Seal Island archipelago; high densities of krill also extended off the shelf from the northeast end of Elephant Island into deeper water. Biomass in the smaller survey area was estimated to be 0.7 million $t$. Three weeks later, high krill densities were still apparent in the vicinity of Seal Island, but the area of high density previously mapped off the northeast end of Elephant Island had diminished considerably; biomass was estimated to be 0.4 million t. During the final survey, conducted 6 wk after the first survey, krill were mapped in reduced densities primarily to the west of Elephant Island; biomass over the larger survey area had declined to 1.1 million $t$.
\end{abstract}

\section{INTRODUCTION}

Antarctic krill Euphausia superba is a key component in the pelagic marine ecosystem of the Southern Ocean (Laws 1985). As much as 300 million metric tons (t) of krill may be consumed annually by 30 million pinnipeds, 50 million sea birds and 300000 baleen whales (Miller \& Hampton 1989). It is also the target of an international fishery (ca $400000 \mathrm{t}$ annually). Although the harvest is less than $1 \%$ of the annual krill production, catches tend to be localized near penguin and fur seal breeding colonies (Agnew in press). The effects of fishing, however, on the reproductive success of land-breeding krill predators has yet to be demonstrated. To do so, it will first be necessary to document the response of predator populations to features of the offshore prey field, and then to determine the effects of fishing on the distribution of prey.

\footnotetext{
- Supported by the John and Fannie Hertz Foundation
}

In response to international concern regarding unregulated development of fisheries in the Southern Ocean, the Convention of the Conservation of Antarctic Marine Living Resources (CCAMLR) was established as part of the Antarctic treaty system in 1982. A principal tenet of the convention is that the harvest of living resources shall be managed with the goal of preserving species diversity and stability of the entire marine ecosystem. Through its Scientific Committee, CCAMLR has encouraged member nations to establish long-term programs to monitor foraging behavior and reproductive success of selected krill predators (SCCAMLR-IV 1985, SC-CAMLR-V 1986, Croxall et al. 1988, Croxall 1989). More recently the Scientific Committee called for descriptions of the prey distribution and abundance in the vicinity of predator monitoring sites and adopted a series of general principles to be used in the design of krill surveys (SC-CAMLR-X 1991). It was recommended that: (1) acoustic data be collected along a series of regularly spaced parallel transects; (2) these data be used to map the distribution 
of krill in the vicinity of a predator monitoring site and estimate their abundance; and (3) more focused surveys, consisting of randomly or regularly spaced parallel transects, be conducted in areas of highest krill density.

A seasonal predator monitoring site has been maintained at Seal Island, off the northwest coast of Elephant Island, Antarctica, since the austral summer of 1986/1987 (Bengtson et al. 1991, Boveng et al. 1991. Croll et al. 1991). An annual series of complementary shipboard observations, including acoustic surveys of zooplankton distribution and abundance, has been conducted in the waters surrounding Elephant Island (Anon. 1990, Rosenberg \& Hewitt 1991, 1992). The acoustic surveys presented in this report are the latest in the series.

Results from previous surveys suggest that the distribution, abundance and demography of krill in the Elephant Island area varies considerably both within and between years (Mathisen \& Macaulay 1983, Kalinowski 1984, Macaulay et al. 1984, Kalinowski et al. 1985, Klindt 1986, Nast 1986, Siegel 1986b, Brinton et al. 1987), and that these changes are due to immigration and emigration of krill rather than local population effects (Priddle 1988, Sahrhage et al. 1988). Spatial separation of adults, sub-adults and juveniles suggests that offshore waters west of the Antarctic Peninsula are krill spawning areas and that the neritic zone may be used as nursery grounds (Fevolden \& George 1984, Quetin \& Ross 1984, Siegel 1986a). Siegel (1988) proposed that adult krill migrate from the southwest (Bellingshausen Sea) into offshore waters during the summer, that sub-adults and juveniles drift to the northeast with the prevailing coastal current, and that the direction of these movements is reversed the autumn. Makaorov et al. (1988) and Nast et al. (1988) noted that Elephant Island lies in the path of a major outlet from the Weddell Sea, and that variations in the position of the Weddell-Scotia Confluence (WSC) may account for the variation in the numbers of krill accumulating in the Elephant Island area from the northern Weddell Sea. Stein (1986) described seasonal variations and meanders in the position of the WSC, which is apparent as a persistent hydrographic front north of Elephant Island. The meanders and eddies in the current flow along the front may be a factor favoring the accumulation of krill in the Elephant Island area, regardless of their origin (Everson 1984, Witek et al. 1988).

Two objectives of our field research program are to: (1) relate the response of krill predators to changes in the availability of their prey; and (2) relate these changes to biotic and abiotic aspects of the pelagic habitat. As such, there is interest in both the spatial patterns of krill distribution as well as their abundance.
The analyses presented here were conducted to reveal features of krill distribution that persisted over relatively large scales (tens of $\mathrm{km}$, and several days). Analyses of these data on finer scales will be reported elsewhere.

\section{METHODS}

Echo integration methods were used to map the distribution of krill and estimate its abundance in the vicinity of Elephant Island. Four surveys were conducted between 19 January and 11 March 1992 (Fig. 1a, b).

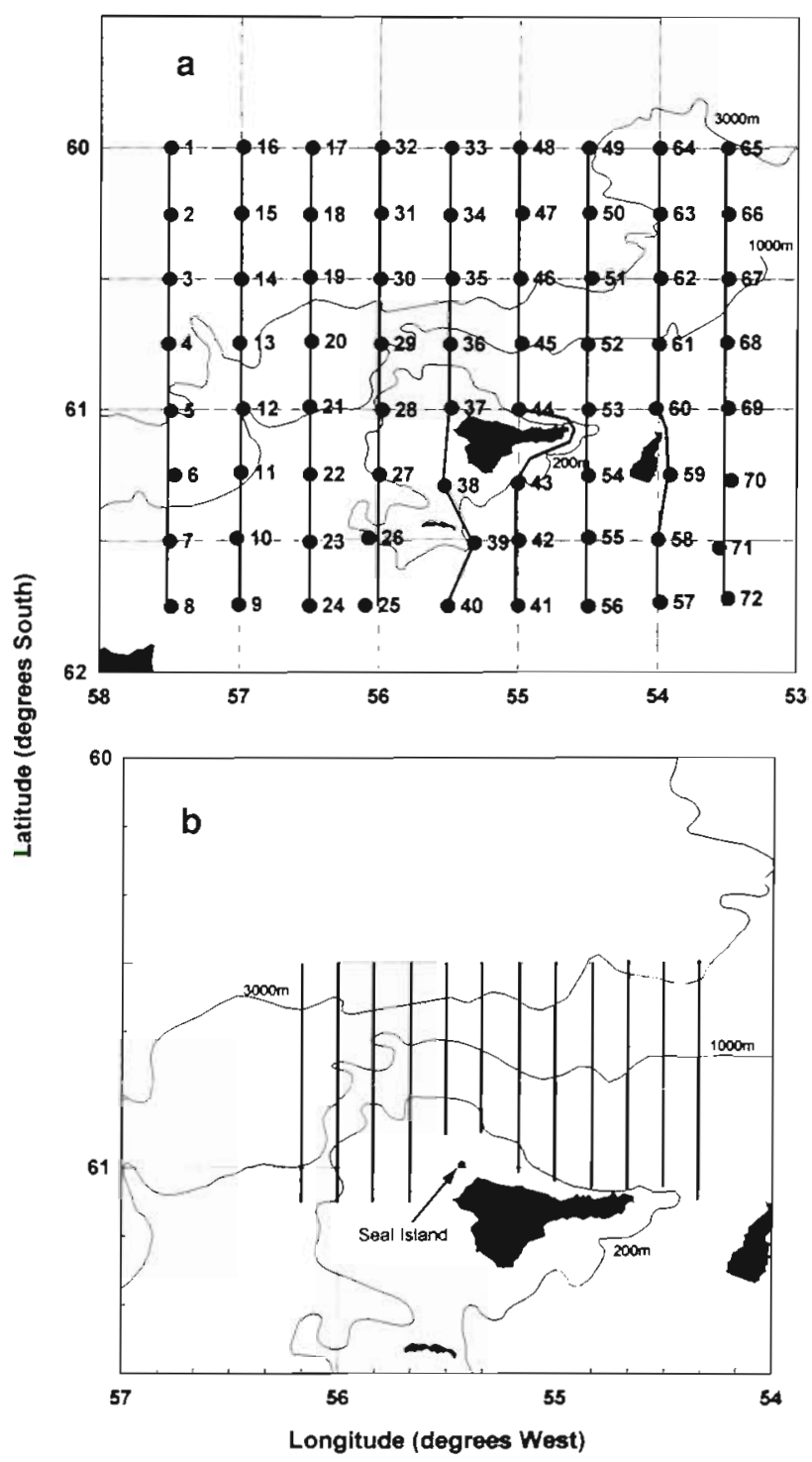

Fig. 1. (a) Station pattern and acoustic transects for Surveys A and D. (b) Acoustic transects for Surveys B and C 
Surveys A and D were designed to describe mesoscale (tens to hundreds of $\mathrm{km}$ ) features of water mass structure, phytoplankton biomass and productivity, and zooplankton constituents (including krill) in the area around Elephant Island. Surveys B and C were designed to map the micro-scale (one to tens of $\mathrm{km}$ ) features of the distribution, density and abundance of krill immediately north of Elephant Island, within the foraging range of krill predators breeding at Seal Island.

Acoustic data were collected with a Simrad EK500 echo sounder (Bodholt et al. 1989) configured with a $120 \mathrm{kHz}$ split-beam transducer. The transducer was deployed on a dead-weight towed body positioned $7 \mathrm{~m}$ below the water surface, and communicated with the echo sounder via $50 \mathrm{~m}$ of armored towing cable, a set of slip rings on the towing winch, and $75 \mathrm{~m}$ of shielded deck cable. The entire system (echo sounder, cables and winch) was calibrated before and after the cruise using standard sphere methods (Johannesson \& Mitson 1983) in a $3 \mathrm{~m}$ diameter by $10 \mathrm{~m}$ deep tank filled with seawater chilled to $0.5^{\circ} \mathrm{C}$; calibration drift was less than $1.2 \mathrm{~dB}$ (Demer \& Hewitt in press).

Echo power levels for each ping were sampled approximately every $3 \mathrm{~cm}$ (25 kHz sampling rate) and adjustments were made for spherical spreading and absorption losses. This data set was averaged every $0.5 \mathrm{~m}$ over depths ranging from 10 to $250 \mathrm{~m}$, and the resulting set of mean volume backscattering strength measurements $\left(s_{V}\right)$ was passed to a computer for further processing and archiving.

Echograms were generated from the subsampled data set and interpreted. The threshold volume backscattering strength was set at $-81 \mathrm{~dB}$ (equivalent to approximately $0.1 \mathrm{krill}^{-3}$ ), and portions of the echogram were attributed to echoes from krill and non-krill (bottom return, system noise, other scatterers). For the purpose of generating distribution maps and biomass estimates, volume backscattering strength attributed to krill was integrated over 10 to $250 \mathrm{~m}$ depth range (or $1 \mathrm{~m}$ above the bottom, if shallower than $250 \mathrm{~m}$ ) and averaged over $1 \mathrm{n}$ mile intervals. Ship's position was also recorded every $10 \mathrm{~s}$ and time-keyed to the acoustic data set. Version 2.6 of the 'Bergen Integrator' software, co-developed by the Bergen Institute of Marine Research, the Christian Michelsen Institute, and Simrad (Knudsen 1990, Foote et al. 1991), was used as an aid in interpreting the echograms and archiving the results.

Mean backscattering area per square $n$ mile of sea surface $\left(s_{A}\right)$ for every $1 \mathrm{n}$ mile of survey transect $\left[\mathrm{m}^{2}(\mathrm{n} \text { mile })^{2}\right]$ was thus calculated by the Bergen Integrator software as:

$$
s_{\mathrm{A}}=4 \pi r_{0}{ }^{2} 1852^{2} \int_{z=10}^{z=250} s_{V} \mathrm{~d} z
$$

where $s_{\mathrm{V}}=0$ if $10 \log \left(s_{\mathrm{V}}\right) \leq-81 \mathrm{~dB} ; z=$ depth; and $r_{0}=$ $1 \mathrm{~m}$ is the reference range for backscattering strength.

By assuming that measurements of $s_{V}$ represent the linear sum of echoes from individual animals within the sample volume (MacLennan \& Simmonds 1992), the numerical density of krill (number per unit area of sea surface) can be estimated by dividing $s_{\mathrm{A}}$ by the backscattering cross-sectional area $\left(\sigma, \mathrm{m}^{2}\right)$ of a single krill. Biomass density of krill $\left(\rho, \mathrm{g} \mathrm{m}^{-2}\right)$ can be estimated by multiplying the numerical density by the weight of a single krill.

Both the backscattering cross-sectional area and the weight of krill are non-linear functions of body length. We used the definition of krill target strength (TS, dB) as a function of standard length $(l)$ as proposed by Greene et al. (1991) and adopted by the CCAMLR Working Group on Krill (SC-CAMLR-X 1991) (see also 'Discussion'):

$$
T S=-127.45+34.85 \log _{10}(l)
$$

where $I=$ standard length of krill $(\mathrm{mm})$. The corresponding backscattering cross-sectional area of krill $(\sigma)$ is:

$$
\sigma=4 \pi r_{0}^{2} 10^{-12745} I^{3485}
$$

The relationship of krill wet wt ( $w, \mathrm{mg}$ ) as a function of standard length was taken from Siegel (1986a) for individuals caught in March:

$$
w=0.00193 l^{3.325}
$$

Thus:

$$
\rho=s_{\mathrm{A}} \frac{w}{\sigma}=0.2491^{-0.16} s_{\mathrm{A}}
$$

Krill were sampled directly with a $6 \mathrm{ft}$ (ca $1.8 \mathrm{~m}$ ) Isaacs-Kidd midwater trawl (IKMT, Devereux 1953), outfitted with a net made of $505 \mu \mathrm{m}$ mesh nytex, and fished obliquely from approximately $170 \mathrm{~m}$ depth to the surface (Loeb \& Siegel in press). Net tows were made at regularly-spaced stations on Surveys A and D (Fig, 1a) without regard to time of day; no net tows were conducted during Surveys B and C. The frequency distribution of krill standard length was used to calculate $\rho$ as follows:

$$
\rho=0.249 \sum_{i=1}^{n} f_{i}\left(l_{t}\right)^{-0.16} s_{\mathrm{A}}
$$

where $f_{1}=$ the relative frequency of krill of standard length $l_{1}$, such that $\sum_{i=1}^{n} f_{1}=1$, where $i$ refers to the $i$ th length class and $n$ is the number of length classes.

A composite frequency distribution of krill standard length was calculated from all net tows conducted during Survey A and used to estimate densities on Surveys $A$ and $B$; similarly a composite frequency distribution was calculated from all net tows conducted during Survey D and used to estimate densities on Surveys C 
and D. The resulting data sets, indexed by time and ship's position, were gridded and contoured for each of the 4 surveys.

Following the method proposed by Hampton (1987) and Jolly \& Hampton (1990), each transect was considered a single sample of biomass density. The entire survey area was treated as a single stratum. Mean biomass density $(\bar{\rho})$ was calculated as a weighted mean:

$$
\bar{\rho}=\frac{\sum_{i=1}^{N} \bar{\rho}_{i}\left(\mathrm{n}_{i}\right)}{\sum_{i=1}^{N} \mathrm{n}_{l}}
$$

where $\bar{\rho}_{1}=$ mean density on the $i$ th transect; $n_{1}=$ no. of $1 \mathrm{n}$ mile averaging-intervals on the $i$ th transect; and $\mathrm{N}=$ no. of transects. Following Jolly \& Hampton (1990) and Simmonds et al. (1991), variance of $\bar{\rho}$ was estimated as:

$$
\bar{\rho}=\frac{N}{N-1} \frac{\sum_{i=1}^{N}\left(\bar{\rho}_{i}-\bar{\rho}\right)^{2} \mathrm{n}_{i}^{2}}{\left(\sum_{i=1}^{N} \mathrm{n}_{i}\right)^{2}}
$$

Biomass was estimated as:

$$
B=A(\bar{\rho})
$$

where $A=$ total survey area $\left(\mathrm{m}^{2}\right)$. Variance of the biomass estimate was calculated as:

$$
\operatorname{var}(B)=A^{2} \operatorname{var}(\bar{\rho})
$$

and the coefficient of variation as:

$$
\mathrm{CV}=\frac{\operatorname{var} \overline{(B)}}{B}
$$

The above expression only reflects the sampling variance (Simmonds et al. 1991). Other potential sources of errors and biases are outlined in the 'Discussion'.

\section{RESULTS}

In late January, krill were distributed in a broad band which extended across the north side of Elephant Island and wrapped around its western end (Survey A, Fig. 2). During a higher resolution survey, conducted during the first week in February, highest krill densities were mapped over the shelf extending to the northwest from Elephant Island and including the Seal Island archipelago. High densities of krill also extended of the shelf from the northeast end of Elephant Island into deeper water (Survey B, Fig. 3).

A similar survey was conducted 3 wk later during the last week in February. Although high krill densities were still apparent in the vicinity of Seal Island, the area of high density previously mapped off the northeast end of Elephant Island had diminished consider- ably (Survey C, Fig. 4). A final survey, similar in areal coverage and sampling intensity to the first survey, was conducted during the first $10 \mathrm{~d}$ of March, $6 \mathrm{wk}$ after Survey A. Both the extent and density of krill were greatly reduced; areas of highest densities were mapped to the west of Elephant Island (Survey D, Fig. 5).

The frequency distribution of krill standard length was bimodal throughout the study period (Fig, 6). Both
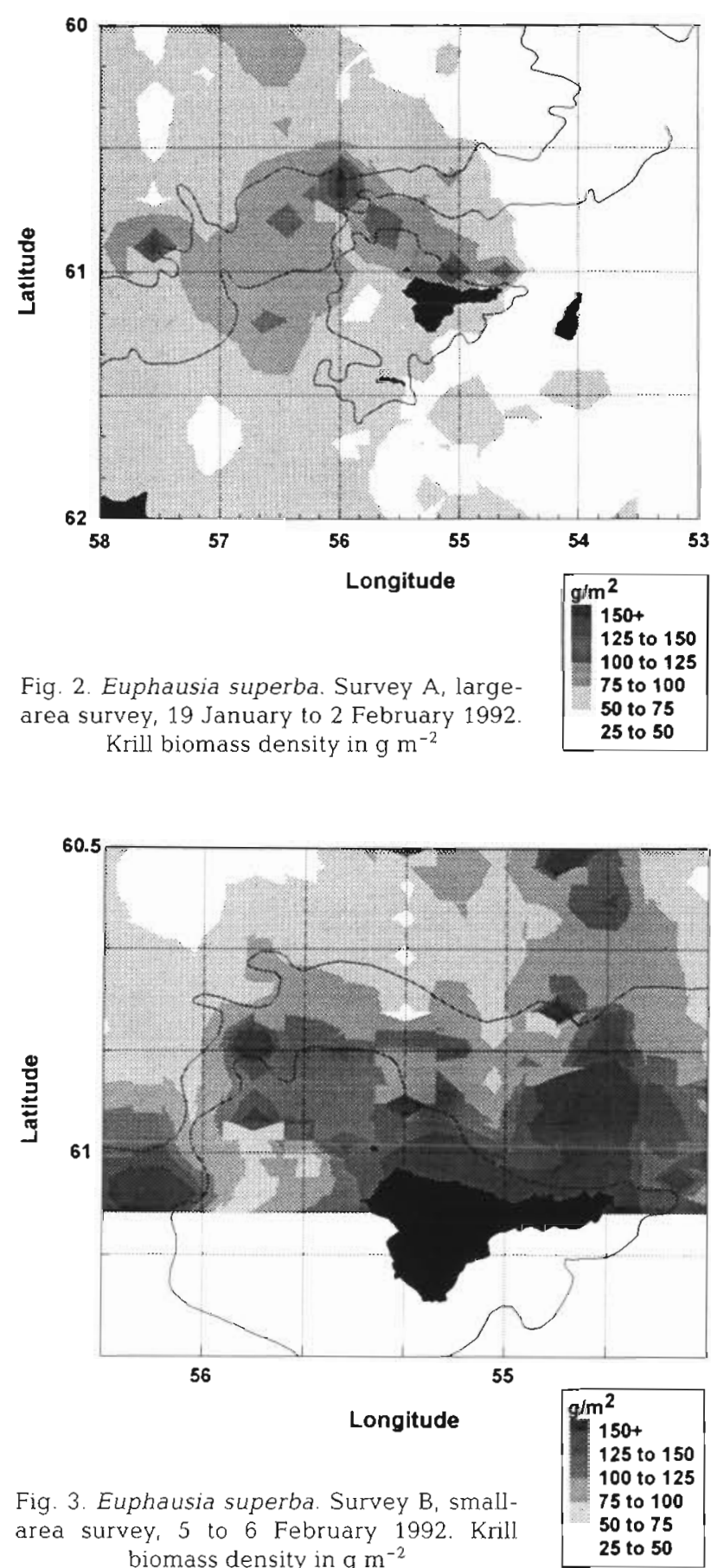

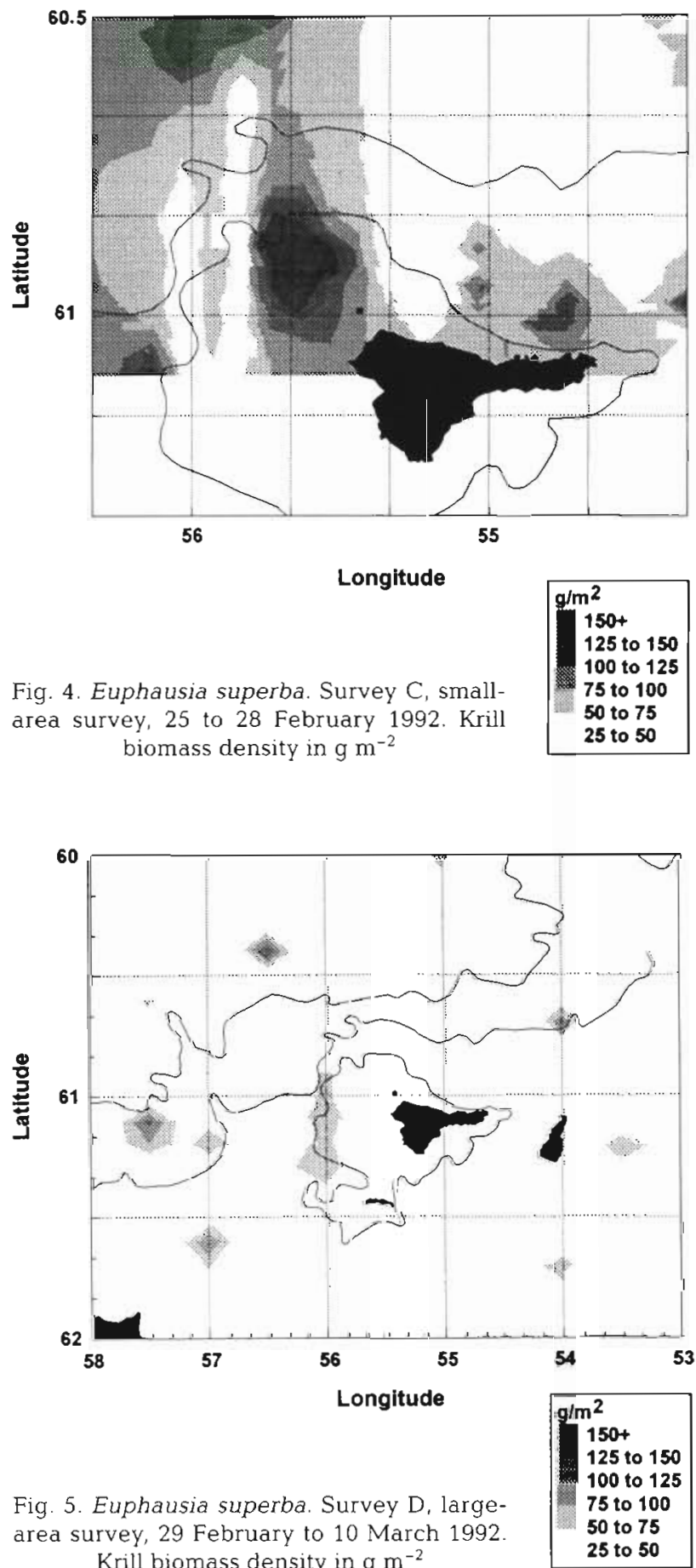

reproductively mature and immature adult krill con-

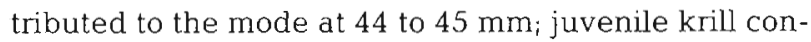
stituted the mode at approximately $28 \mathrm{~mm}$ (Loeb \& Siegel in press). Relative to Survey A, greater proportions of intermediate-sized krill and reduced proportions of smaller sizes were caught during Survey D. The size frequency obtained during Survey A was used to calculate krill densities on Surveys $A$ and $B$,
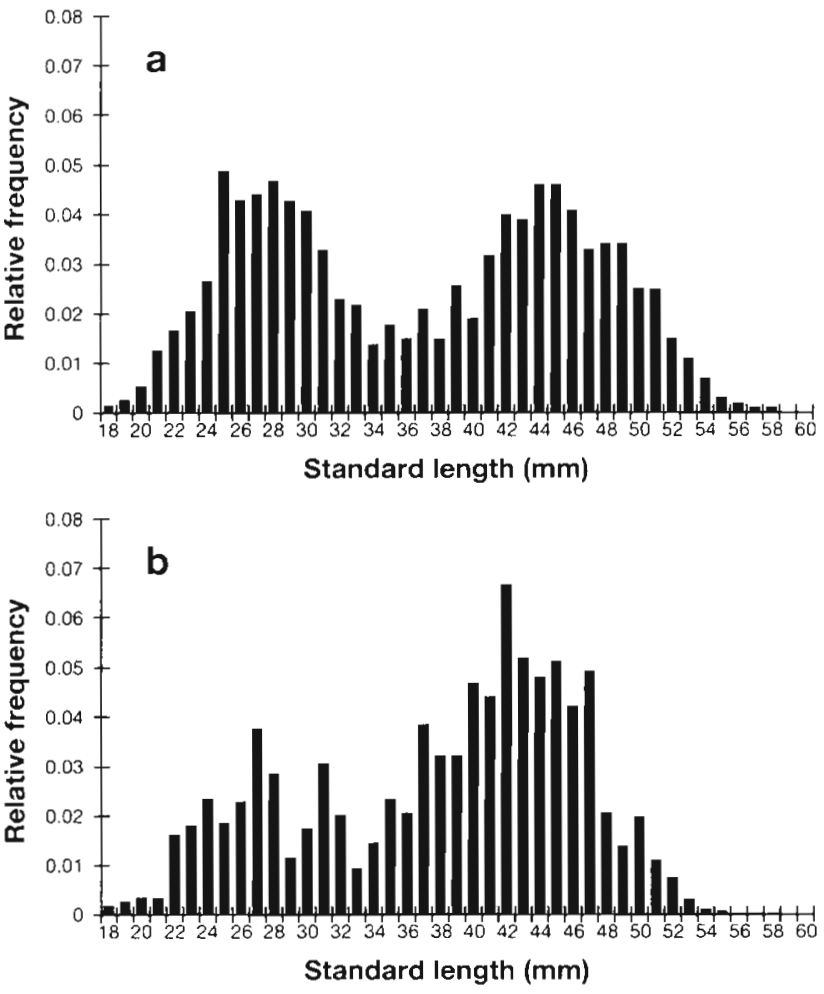

Fig. 6. Euphausia superba. Frequency distributions of krill standard length collected during (a) Survey A and (b) Survey B. From Loeb \& Siegel (in press)

and the size frequency of krill obtained during Survey $D$ was used to calculate krill densities on Surveys C and $D$.

During the first large-area survey (Survey A) krill abundance was estimated at 2.2 million $t, C V=16 \%$. Six weeks later (Survey D) krill abundance over the same area was estimated to be 1.1 million $\mathrm{t}, \mathrm{CV}=9 \%$. Estimated abundance during the first small-area survey (Survey B) was 0.7 million $t, C V=22 \%$, and during the second small-area survey (Survey C) it was 0.4 million $t, C V=23 \%$ (Table 1 ).

\section{DISCUSSION}

Several sources of error associated with the echo integration method can be identified. These include both random errors and systematic biases associated with the definition of individual krill target strength, estimating the size distribution of krill in the surveyed population, species identification, estimating the amount of undetected krill, assumption of a linear addition of echoes from individual krill in the sample volume, estimating system gain and absorption loss, and estimating survey sampling error. 
Table 1. Euphausia superba. Abundance estimates for Surveys $A, B, C$ and $D$. $\mathrm{nl}_{1}$ : no. of $1 \mathrm{n}$ mile averaging intervals on the ith transect; $s_{A}$ : mean backscattering area per $n$ mile ${ }^{2}$ of sea surface; $\bar{\rho}$ : mean biomass density; Var $(\bar{\rho})$ : variance of $\bar{\rho}_{i} C V:$ coefficient of variation

\begin{tabular}{|c|c|c|c|c|c|c|c|c|}
\hline & \multicolumn{2}{|c|}{ Survey A } & \multicolumn{2}{|c|}{ Survey B } & \multicolumn{2}{|c|}{ Survey C } & \multicolumn{2}{|c|}{ Survey D } \\
\hline & $n_{i}$ & $s_{A}$ & $\mathrm{n}_{1}$ & $s_{A}$ & $\mathrm{n}_{1}$ & $s_{\mathrm{A}}$ & $\mathrm{n}_{2}$ & $s_{\mathrm{A}}$ \\
\hline Transect 1 & 113 & 386.3 & 30 & 714.9 & 47 & 725.9 & 110 & 264.0 \\
\hline Transect 2 & 95 & 374.5 & 37 & 188.6 & 35 & 512.7 & 98 & 254.8 \\
\hline Transect 3 & 108 & 814.9 & 35 & 979.5 & 38 & 160.5 & 103 & 223.1 \\
\hline Transect 4 & 112 & 590.6 & 35 & 470.7 & 37 & 1155.2 & 106 & 332.9 \\
\hline Transect 5 & 127 & 451.1 & 27 & 386.9 & 29 & 648.0 & 110 & 150.0 \\
\hline Transect 6 & 137 & 473.4 & 24 & 590.0 & 25 & 55.2 & 133 & 169.9 \\
\hline Transect 7 & 115 & 231.5 & 31 & 918.2 & 29 & 34.9 & 109 & 166.6 \\
\hline Transect 8 & 117 & 178.9 & 28 & 67.8 & 37 & 400.5 & 116 & 192.8 \\
\hline Transect 9 & - & - & 37 & 1220.0 & 32 & 219.9 & 116 & 174.4 \\
\hline Transect 10 & - & - & 35 & 1990.3 & 37 & 337.5 & - & - \\
\hline Transect 11 & - & - & 33 & 353.5 & 32 & 144.6 & - & - \\
\hline Transect 12 & - & - & 34 & 529.6 & 38 & 374.1 & - & - \\
\hline$\sum n_{1}$ & \multicolumn{2}{|c|}{924} & \multicolumn{2}{|c|}{386} & \multicolumn{2}{|c|}{416} & \multicolumn{2}{|c|}{1001} \\
\hline Weighted mean & \multirow{2}{*}{\multicolumn{2}{|c|}{$\begin{array}{r}436.2 \\
4722.5\end{array}$}} & \multirow{2}{*}{\multicolumn{2}{|c|}{$\begin{array}{r}721.8 \\
257232\end{array}$}} & \multicolumn{2}{|c|}{421.3} & \multicolumn{2}{|c|}{211.9} \\
\hline Weighted variance & & & & & & 6.1 & & \\
\hline $0.249 \sum_{i=1}^{\mathrm{n}} f_{i}\left(I_{i}\right)^{-0.16}$ & \multicolumn{2}{|c|}{0.1403} & \multicolumn{2}{|c|}{0.1403} & \multicolumn{2}{|c|}{0.1398} & \multicolumn{2}{|c|}{0.1398} \\
\hline $\bar{\rho}\left(\mathrm{g} \mathrm{m}^{-2}\right)$ & \multicolumn{2}{|c|}{61.20} & \multicolumn{2}{|c|}{101.27} & \multicolumn{2}{|c|}{58.90} & \multicolumn{2}{|c|}{29.63} \\
\hline $\operatorname{Var}(\bar{\rho})$ & \multicolumn{2}{|c|}{92.96} & \multicolumn{2}{|c|}{506.34} & \multicolumn{2}{|c|}{176.99} & \multicolumn{2}{|c|}{7.50} \\
\hline Survey area (n mile ${ }^{2}$ ) & \multicolumn{2}{|c|}{10575} & \multicolumn{2}{|c|}{2100} & \multicolumn{2}{|c|}{2100} & \multicolumn{2}{|c|}{10575} \\
\hline Survey area $\left(A, \times 10^{6} \mathrm{~m}^{2}\right)$ & \multicolumn{2}{|c|}{36271} & \multicolumn{2}{|c|}{7203} & \multicolumn{2}{|c|}{7203} & \multicolumn{2}{|c|}{36271} \\
\hline Biomass $\left(B, \times 10^{3} t\right)$ & \multicolumn{2}{|c|}{2220} & & & & 24 & & \\
\hline $\mathrm{CV}(\%)$ & & & & & & .59 & & \\
\hline
\end{tabular}

Foote et al. (1990) noted that abundance estimates of krill using acoustics were often much less than those obtained from estimates of predator demand. They suspected large errors associated with the definition of individual krill target strength, and ensonified live krill aggregations in a cage at $120 \mathrm{kHz}$. The mean singleanimal target strength of 30 to $39 \mathrm{~mm}$ krill was inferred from the aggregation backscatter to range from -81 to $-74 \mathrm{~dB}$. Everson et al. (1990) noted that these values were considerably lower that those calculated from previously used equations relating target strength to the physical size of krill (BIOMASS 1986), and that the use of these equations resulted in gross underestimates of krill abundance. Until recently, a fluid sphere model was used to characterize the target strength of krill. Wiebe et al. (1990) ensonified several species of live, but tethered, zooplankton at $420 \mathrm{kHz}$ and concluded that sound scatter from elongated animals is better described by a bent cylinder model (Stanton 1989), and that target strength is proportional to the volume of an animal rather than its cross-sectional area. Using these data, Greene et al. (1991) predicted krill target strength at several frequencies and over a range of body lengths. The Foote et al. (1990) data agreed with the Greene et al. (1991) prediction. Further corroboration was offered by Hewitt \& Demer
(1991) who reported a set of in situ target strength measurements using a $120 \mathrm{kHz}$ split-beam transducer. For krill with an estimated mean length of $47.4 \mathrm{~mm}$, the modal target strength was $-69 \mathrm{~dB}$, within $1 \mathrm{~dB}$ of the prediction by Greene et al. (1991). The CCAMLR Working Group on Krill reviewed these and several unpublished studies on krill target strength and concluded that 'a growing body of evidence suggests that the BIOMASS definition of target strength as a function of body length at $120 \mathrm{kHz}$ consistently overestimates target strength', and that 'measurements over a range of animal lengths imply a stronger dependence of target strength on length than that predicted by the BIOMASS definition' (SC-CAMLR-X 1991). Although the Greene et al. (1991) equation is a currently accepted estimator of krill target strength, body shape, orientation and physical condition also affect target strength (Stanton 1989). The range of variation of these parameters should be measured under conditions when the krill would be surveyed, and used in theoretical models to predict the distribution of individual target strengths that would be expected from a natural aggregation of krill (SC-CAMLR-X 1991).

Estimates of krill biomass density are insensitive to minor variations in the frequency distribution of length. This is because the number of krill per $\mathrm{kg}$ 
Table 2. Euphausia superba. Krill weight, numbers per $\mathrm{kg}$, target strength (TS) per individual, TS per $\mathrm{kg}$, backscattering crosssection per $\mathrm{kg}$, and $\mathrm{kg}$ per backscattering cross-section by standard length

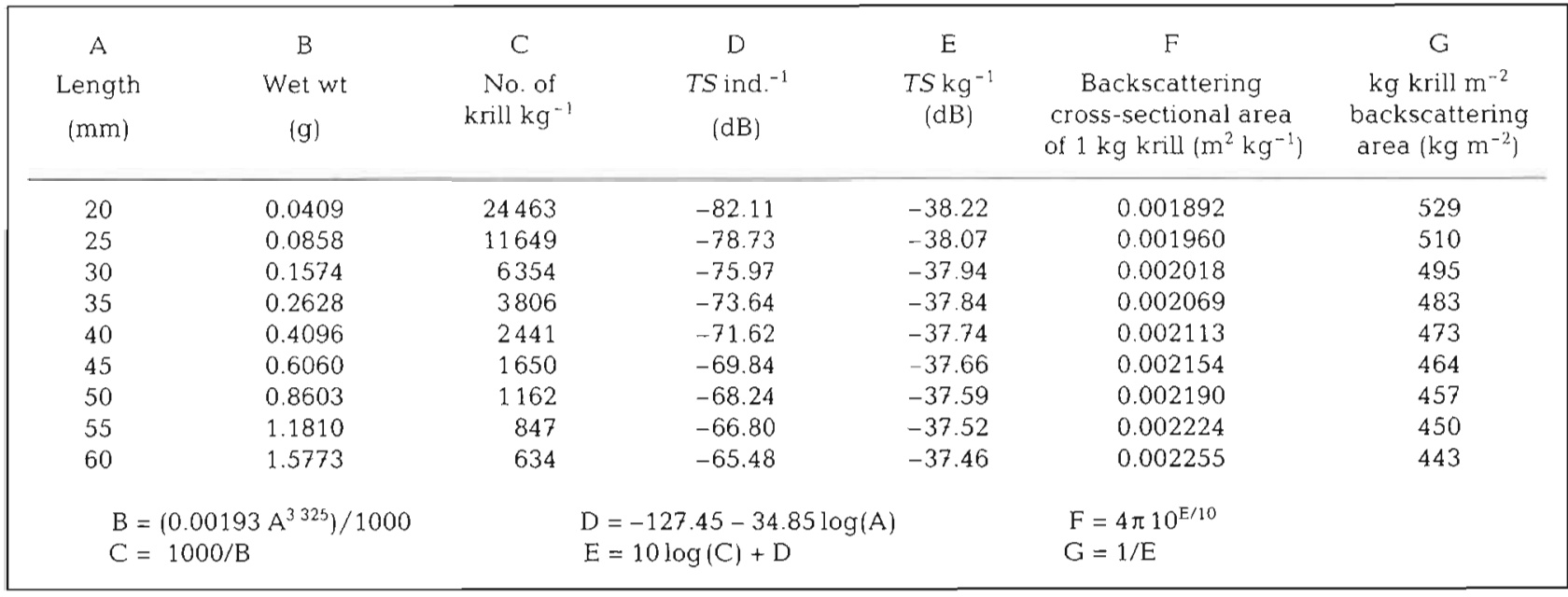

decreases exponentially with increasing length at approximately the same rate as the backscattering crosssectional area of a single krill increases with increasing length. The dependence of weight, numbers per $\mathrm{kg}$, target strength per individual, target strength per $\mathrm{kg}$, backscattering cross-sectional area per $\mathrm{kg}$ and $\mathrm{kg}$ per $\mathrm{m}^{2}$ of backscattering area on standard length are illustrated in Table 2 and Fig. 7 a to e. As can be seen from Table 2 , the factor relating krill biomass to backscattering area varies from 529 to $443 \mathrm{~kg} \mathrm{~m}^{-2}$ of backscattering area over a range of krill lengths from 20 to $60 \mathrm{~mm}$. This implies that mean length may be used to calculate biomass densities without introducing substantial errors. If, on the other hand, numerical densities are desired (e.g. for studies of foraging behavior) then body length is critical to accurate estimates.

Species identification is problematic. Several highresolution Multiple Opening-Closing Net and Environmental Sampling System (MOCNESS) tows were aimed at specific echogram types. Swarming krill appear quite different from the other major sources of zooplankton sound scattering (other euphausids, primarily Thysanoessa macrura; amphipods, primarily Themisto gaudichaudii; copepods; and salps): the edges of krill swarms, although irregular, are very sharp and distinct, and the volume backscattering strength of krill aggregations is much higher than that for other taxa. Although the total number of non-krill zooplankton caught in the IKMT tows exceeded that of

Fig. 7. Euphausia superba. Dependence of (a) krill weight, (b) numbers per $\mathrm{kg}$, (c) target strength per individual, (d) target strength per $\mathrm{kg}$, and (e) $\mathrm{kg}$ per backscattering crosssection, on standard length
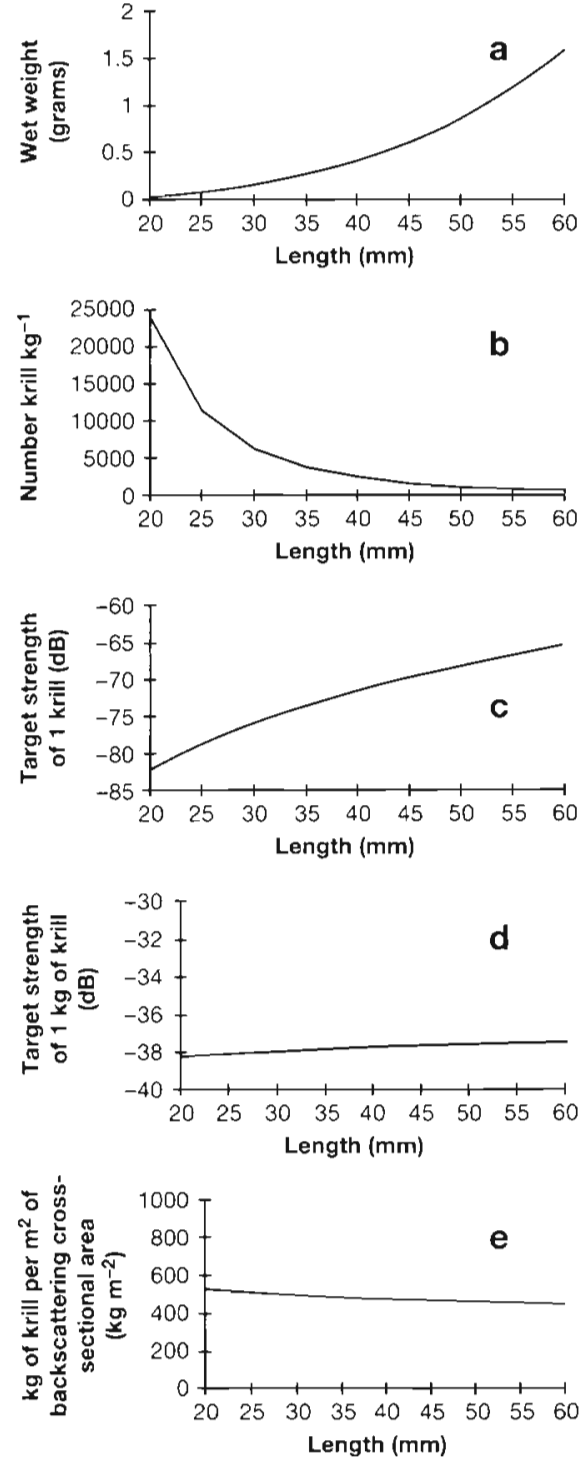
krill (Loeb et al. 1992), their aggregate backscattering strength, estimated by assuming that target strength of elongated zooplankton is proportional to the cube of their length (Wiebe et al. 1990), was less than $10 \%$ of that from krill over the survey area. Backscattering from krill and non-krill zooplankton were lumped together and biomass estimates are thus biased slightly upward. Although Salpa thompsoni were the most abundant non-krill zooplankton, they were not included in the above calculation because as gelatinous tunicates they are unlike any taxa included in Wiebe et al. (1990) experiments. Because they are mostly water and lack a strong density contrast, salps are probably not efficient sound scatterers. Although the numerical density of salps was higher than that of krill in IKMT samples collected in the southern and eastern portions of the large-area surveys, the integrated backscattering strength in these areas was low

Krill within $10 \mathrm{~m}$ of the surface, below $250 \mathrm{~m}$, and more dispersed than a threshold density of approxi-

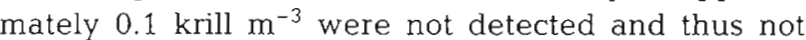
included in the biomass estimates. Survey effort was not adjusted for the time of day so that the amount of undetected krill could have varied with diel changes in krill behavior. Ship's position was independent of time of day, however, and any diel effects should be random error added to the estimate of systematic bias caused by undetected krill. There were accasions when surface swarms were observed during daylight hours; and krill were sometimes entrained in the ship's cooling water intake during the day, although more frequently at night. The amount of krill in the upper $10 \mathrm{~m}$, however, can be a substantial, but unknown, portion of that in the entire water column, and a potentially large source of error. This region could be investigated by using side-looking and up-looking transducers. In their review, Miller \& Hampton (1989) note that krill are principally found in the upper $150 \mathrm{~m}$ of the water column. The lack of evidence to the contrary, however, does not preclude substantial numbers of krill below $250 \mathrm{~m}$ depth. Lower frequency echo sounders, acoustic transducers mounted on remote vehicles, and/or deeper fishing nets could be used to detect krill deeper than $250 \mathrm{~m}$. The maximum density of undetected dispersed krill, assuming a density of $0.1 \mathrm{krill} \mathrm{m}^{-3}$ throughout the upper $250 \mathrm{~m}$ and an average individual weight of $0.5 \mathrm{~g}$, is less than $10 \%$ of the average density of the 4 surveys. It is very unlikely that undetected krill would be present throughout the water column at just below the threshold density, and thus errors due to non-detection of dispersed krill are considered negligible

Foote (1983) demonstrated that it was reasonable to assume that volume backscattering strength from fish schools was the result of incoherent addition of echoes from individual fish within the sample volume. The linear relationship between backscattering strength and density breaks down, however, at very high animal densities due to the effects of shadowing and multiple scattering (MacLennan \& Simmonds 1992). Although peak $s_{V}$ values indicated krill densities on the order of $10^{3}$ ind. $\mathrm{m}^{-3}$, shadowing may have occurred, particulary with thick swarms and layers. Evidence of multiple scattering was observed occasionally in association with very dense swarms. This ringing, observed as diffuse echoes below the more solid return from the swarm, was included in the integration with the expectation that multiple scattering helps offset the effect of shadowing (Stanton 1983).

Calibration inaccuracies can also contribute to the error in integration survey results. Foote \& MacLennan (1984) stated that precision calibration to within $0.5 \mathrm{~dB}$ is possible by using standard calibration spheres. This translates to a $1 \mathrm{~dB}$ error in estimating mean target strength. Robinson (1984) noted that the acoustic absorption coefficient at $120 \mathrm{kHz}$ is not known better than $\pm 0.5 \mathrm{~dB} \mathrm{~km}^{-1}$. This implies that, at a range of $50 \mathrm{~m}$, calibration accuracy can be no better than \pm 0.5 $\mathrm{dB}$ due to this parameter alone. Our calibration experiments using various pulse lengths and sphere materials indicated system gain variations of as much as 1.2 and $1.5 \mathrm{~dB}$, respectively (Demer \& Hewitt in press).

Application of Jolly \& Hampton's (1990) formula for estimating variance is valid only if the parallel survey transects are randomly spaced. Because the intent was to derive distribution maps as well as estimate abundance, transects were regularly spaced and Jolly \& Hampton's expression for variance was used as an approximation. As such it is an underestimate of the true survey sampling variance.

The range of estimates of krill abundance in the Elephant Island area reported here is within the range of previously reported values. Macaulay et al. (1984) estimated that 2.1 million t of krill were aggregated in a large swarm located over the shelf break north of Elephant Island. Acoustic surveys conducted by Macaulay in the austral summers of 1981, 1984, 1987 , 1988 and 1989, when normalized to a survey area of $5055 \mathrm{n}$ mile ${ }^{2}$ centered on Elephant Island, resulted in biomass estimates of $0.8,0.3,0.7,0.5$ and 0.9 million $t$ respectively (Macaulay unpubl.). Macaulay (pers. comm.) assumed the target strength of 40 to $45 \mathrm{~mm}$ krill to be $-35.93 \mathrm{~dB} \mathrm{~kg}^{-1}$; incorporating the more recent definition of krill target strength $\left(-37.70 \mathrm{~dB} \mathrm{~kg}^{-1}\right.$, Table 2) results in adjusted biomass estimates of 1.2 , $0.4,1.0,0.7$ and 1.4 million t. Klindt (1986) reported biomass estimates from combined acoustic and net surveys conducted in the Elephant Island area during 1983, 1984 and 1985 of $0.05,0.4$ and 0.02 million $t$ respectively. Klindt used the BIOMASS (1984) definition 
Table 3. Euphausia superba. Acoustic estimates of krill biomass in the Elephant Island area

\begin{tabular}{|c|c|c|c|c|c|}
\hline Year & Month & $\begin{array}{l}\text { Survey area } \\
\left.\text { (n mile }{ }^{2}\right)\end{array}$ & $\begin{array}{l}\text { Biomass } \\
\left(\times 10^{3} \mathrm{t}\right)\end{array}$ & $\begin{array}{l}\text { Adj. biomass } \\
\left.\qquad \times 10^{3} \mathrm{t}\right)\end{array}$ & Source \\
\hline 1981 & March & 5055 & $790^{\circ}$ & 1187 & Macaulay (unpubl.) \\
\hline 1983 & October/November & 10507 & 52 & 480 & Klindt $(1986)$ \\
\hline 1984 & March & 5055 & 260 & 390 & Macaulay (unpubl.) \\
\hline 1984 & November/December & 10106 & 380 & 2200 & Klindt (1986) \\
\hline 1985 & March/April & 9283 & 16 & 81 & Klindt (1986) \\
\hline 1987 & January & 5055 & 660 & 992 & Macaulay (unpubl.) \\
\hline 1988 & January & 5055 & 480 & 721 & Macaulay (unpubl.) \\
\hline 1989 & February & 5055 & $950^{a}$ & 1428 & Macaulay (unpubl.) \\
\hline \multirow[t]{4}{*}{1990} & Early January & 11925 & 465 & 699 & Amos et al. (1990) \\
\hline & Late January & 10575 & 1132 & 1702 & Amos et al. (1990) \\
\hline & Early February & 11925 & 2133 & 3206 & Amos et al. (1990) \\
\hline & Late February & 11925 & 2475 & 3720 & Amos et al. (1990) \\
\hline \multirow[t]{2}{*}{1991} & Late January & 12675 & 689 & 1036 & Macaulay \& Mathisen (1991) \\
\hline & Late Feb. - early Mar. & 12525 & 822 & 1236 & Macaulay \& Mathisen (1991) \\
\hline \multirow[t]{2}{*}{1992} & Late January & 10575 & 2220 & 2220 & This report \\
\hline & Early March & 10575 & 1075 & 1075 & This report \\
\hline
\end{tabular}

of target strength adjusted to $150 \mathrm{kHz}$ and the length frequency distributions reported by Siegel (1986a). Klindt's biomass estimates may be adjusted by a factor corresponding to the difference in target strength at $120 \mathrm{kHz}$ using the modal krill lengths for each of the surveys $(30,41$ and $45 \mathrm{~mm})$; the corresponding factors $(9.2,5.8$ and 4.9$)$ result in adjusted biomass estimates of $0.5,2.2$ and 0.1 million t. Four surveys were conducted by Macaulay in the Elephant Island area during January and February 1990 (Amos et al. 1990). Estimated krill biomass increased from the first survey through the fourth survey $(0.5,1.1,2.1$ and 2.4 million t). Two surveys were conducted by Macaulay between mid-January and mid-February 1991 (Macaulay \& Mathisen 1991). Estimated krill biomass increased from 0.7 to 0.8 million t. For the 1990 and 1991 surveys, Macaulay (pers. comm.) again used $-35.93 \mathrm{~dB} \mathrm{~kg}^{-1}$ to scale his biomass estimates; adjusted biomass estimates are $0.7,1.7,3.2$ and 3.7 million $t$ for 1990, and 1.0 and 1.2 million $t$ for 1991. Results from the above surveys are summarized in Table 3

Krill abundance in the Elephant Island area decreased over the 2 mo observational period of midJanuary to mid-March 1992. Krill abundance decreased approximately 2 -fold between the 2 large-area surveys, Surveys A and D, conducted in the waters surrounding Elephant Island. Krill abundance also decreased approximately 2 -fold between the 2 smallarea surveys conducted to the north of Elephant Island, Surveys B and C. This was in marked contrast to the results from surveys conducted in 1990 and 1991 when krill abundance increased from mid-January to midMarch.
Over the last $3 \mathrm{yr}$, several measures of reproductive success of chinstrap penguins Pygoscelis antarctica at Seal Island varied in concert with estimates of krill biomass: moderately high in 1990, very low in 1991, and very high in 1992 (D. A. Croll pers. comm.). Seasonal variations in the availability of krill to predators may also be important. Although average abundances of krill during the 1990 and 1992 austral summer were similar, the seasonal timing of peak abundance was quite different - late in 1990, early in 1992. Reproductive success of chinstrap penguins was high in 1992 relative to 1990 . Good breeding success early in the 1992 season, however, may be countered by the lack of krill late in the season when local demand for prey by newly fledged chicks and adults about to molt may be at its highest (Croll in press).

Acknowledgements. This work was supported by the National Oceanic and Atmospheric Administration as part of its Antarctic Marine Living Resources (AMLR) program. We thank Duncan McGehee, Jane Rosenberg, Stephanie Sexton and Rennie Holt for their assistance in collecting the acoustic data; Valerie Loeb for providing data on the size distribution of krill; and the officers and crew of the NOAA Ship 'Surveyor' for their help and support. Helpful comments were also received from 3 anonymous reviewers.

\section{LITERATURE CITED}

Agnew, D. J. (in press). Krill catch distribution in relation to predator colonies, 1987-1991. Selected Scientific Papers of the CCAMLR Scientific Committee 1992, Hobart

Amos, A. F., Bengtson, J. L., Holm-Hansen, O., Loeb, V. J., Macaulay, M. C., Wormuth, J. H. (1990). Surface water 
masses, primary production, krill distribution and predator foraging in the vicinity of Elephant Island during the 1989-90 austral summer. CCAMLR-WG-CEMP-90/11, Hobart

Anon. (ed.) (1990). AMLR 1989/90 field season report: objectives, accomplishments, and tentative conclusions. SWFSC Admin. Rep. LJ-90-11. Southwest Fisheries Science Center, La Jolla, CA, p. 1-104

Bengtson, J. L., Boveng, P., Jansen, J. K. (1991). AMLR Program: foraging areas of krill-consuming penguins and fur seals near Seal Island, Antarctica. Antarct. J. U.S. 26(5): 217-218

BIOMASS (1986). Report on post-FIBEX acoustic workshop. Frankfurt, Germany, September 1984. BIOMASS Report Series No. 40. SCAR. Cambridge, p. 1-128

Bodholt, H., Nes, H., Solli, H. (1989). A new echo-sounder system. Proc. IOA 11(3): 123-130

Boveng, P., Bengtson, J. L., Jansen, J. K. (1991). AMLR Program: Antarctic fur seal foraging patterns at Seal Island, South Shetland Islands, Antarctica, during austral summer 1990-91. Antarct. J. U.S. 26(5): 215-216

Brinton, E., Loeb, V. J., Macaulay, M. C., Shulenberger, E. (1987). Variability of Euphausia superba populations near Elephant Island and the South Shetland Islands: 1981 vs 1984. Polar Biol. 7: 345-362

Croll D. A. (1990). Estimation of the energy and prey requirements of predators breeding on the South Shetland Islands, CCAMLR-WG-CEMP-90/30, Hobart

Croll, D. A., Jansen, J. K., Bengtson, J. L. (1991). AMLR Program: reproductive performance of chinstrap penguins on Seal Island, South Shetland Islands, Antarctica. Antarct. J. U.S. 26(5): 218-220

Croxall, J. P. (1989). Use of indices of predator status and performance in CCAMLR fishery management. Selected Scientific Papers of the CCAMLR Scientific Committee 1989, Hobart, p. 353-365

Croxall, J. P., McCann, T. S., Prince, P. A., Rothery, P. (1988). Reproductive performance of seabirds and seals at South Georgia and Signy Island, South Orkney Islands 1976-1987: implications for Southern Ocean monitoring studies. In: Sahrhage, D. (ed.) Antarctic Ocean and resources variability. Springer-Verlag, Berlin, p. 262-285

Demer, D. A., Hewitt, R. P. (in press). Calibration of an acoustic echo-integration system in a deep tank, with gain comparisons over standard sphere material, water temperature and time. Selected Scientific Papers of the CCAMLR Scientific Committee 1992, Hobart

Devereux, R. F. (1953). Isaacs-Kidd midwater trawl. Scripps Institution of Oceanography, La Jolla, Refer. 53-3: 1-21

Everson, I. (1984). Zooplankton. In: Laws, R. M. (ed.) Antarctic ecology, Vol. 2. Academic Press, London, 491-532

Everson, I., Watkins, J. L., Bone, D. G., Foote, K. G. (1990). Implications of a new acoustic target strength for abundance estimates of Antarctic krill. Nature 345: 338-340

Fevolden, S. E., George, R. Y (1984). Size frequency pattern of Euphausia superba in the Antarctic Peninsula waters in the austral summer of 1983. J. crust. Biol. 4 (Spec. No. 1): $107-122$

Foote, K. G. (1983). Linearity of fisheries acoustics, with addition theorums. J. Acoust. Soc. Am. 73: 1932-1940

Foote, K. G., Everson, I., Watkins, J. L., Bone, D. G. (1990). Target strengths of Antarctic krill (Euphausia superba) at 38 and $120 \mathrm{kHz}$. J. Acoust. Soc. Am. 87: 16-24

Foote, K. G., Knudsen, H. P., Korneliussen, R. J., Norbø, P. E., Roang, K. (1991). Postprocessing system for echo sounder data. J. Acoust. Soc. Am 90(1): 37-47

Foote, K. G., MacLennan, D. N. (1984). Comparison of copper and tungsten carbide spheres. J. Acoust. Soc. Am. 75 $612-616$

Greene, C. H., Stanton, T K., Wiebe, P. H., McClatchie, S (1991). Acoustic estimates of Antarctic krill. Nature 349 110

Hampton, I. (1987). Acoustic study on the abundance and distribution of anchovy spawners and recruits in South African waters. In: Payne, A. I. L., Gulland, J. A., Brink, K. H. (eds.) The Benguela and comparable ecosystems S. Afr. J. mar. Sci. 5: 901-917

Hewitt, R. P., Demer, D. A. (1991). Krill abundance. Nature 353: 310

Johannesson, K. A., Mitson, R. B. (1983) Fisheries acoustics: a practical manual for aquatic biomass estimation. FAO Tech. Pap. No. 240, Rome, p. 1-249

Jolly, G. M., Hampton, I. (1990). A stratified random transect design for acoustic surveys of fish stocks. Can. J. Fish. Aquat. Sci. 47: 1282-1291

Kalinowski, J. (1984). The biomass of krill in the eastern part of the Bransfield Strait, March, 1981. Pol, polar Res. 5: $99-105$

Kalinowski, J., Godlowska, M., Klusek, Z. (1985). Distribution and stock of krill in the Bransfield Strait and Drake Passage during December 1983 - January 1984. Pol. polar Res. 6: 151-158

Klindt, H. (1986). Acoustic estimates of the distribution and stock size of krill around Elephant Island during SIBEX I and II in 1983, 1984, and 1985. Arch. FischWiss. 37 $107-127$

Knudsen, P. (1990). The Bergen Echo Integrator: an introduction. J. Cons. int. Explor. Mer 47: 167-174

Laws, R. M. (1985). The ecology of the Southern Ocean. Am. Scient. 73: 26-40

Loeb, V., Davis, K., Roddy, F., Siegel, V., Kelly, D. (1992). Direct krill and zooplankton sampling. In: Rosenberg, J., Hewitt, R. (eds.) AMLR 1991/92 field season report. SWFSC Admin. Rep. LJ-92-17. Southwest Fisheries Science Center, La Jolla, CA, p. 51-66

Loeb, V., Siegel, V. (in press). AMLR Program: krill stock structure in the Elephant Island area, January-March 1992. Antarct. J. U.S.

Macaulay, M. C., English, I. S., Mathisen, O. A. (1984). Acoustic characterization of Antarctic krill (Euphausia superba) from Elephant Island and Bransfield Strait. J. crust. Biol. 4 (Spec. No. 1): 16-44

Macaulay, M. C., Mathisen, O. A. (1991). AMLR Program: hydroacoustic observations of krill distribution and biomass near Elephant Island, austral summer 1991. Antarct. J. U.S. 26(5): 203-204

MacLennan, D. N., Simmonds, E. J. (1992). Fisheries acoustics. Chapman and Hall, London

Makaorov, R. R., Maslennikov, V. V., Solyankin, E. V., Spiridonov, V. A., Yakolev, V. N. (1988). Variability in population density of Antarctic krill in the western Scotia Sea in relation to hydrological conditions. In: Sahrhage, D. (ed.) Antarctic Ocean and resources variability. SpringerVerlag, Berlin, p. 231-236

Mathisen, O. E., Macaulay, M. C. (1983). The morphological features of a super-swarm of krill, Euphausia superba. Mem. Nat. Inst. Polar Res. Spec. Issue No. 27: 153-164

Miller, D. G. M. Hampton, I. (1989). Biology and ecology of the Antarctic krill (Euphausia superba): a review. BIOMASS Sci. Ser. No. 9: 1-166

Nast, F. (1986). Changes in krill abundance and in other zooplankton relative to the Weddell-Scotia Confluence around Elephant Island in November 1983, November 1984 and March 1985. Arch. FischWiss. 37: 73-94 
Nast, F., Kock, K.-H., Sahrhage, D., Stein, M., Tiedtke, J E. (1988). Hydrography, krill and fish and their possible relationships around Elephant Island. In: Sahrhage, D. (ed.) Antarctic Ocean and resources variability. SpringerVerlag, Berlin, p. 183-198

Priddle, J., Croxall, J. P., Everson, I., Heywood, R. B., Murphy, E. J., Prince, P. A., Sear, C. B. (1988). Large-scale fluctuations in distribution and abundance of krill - a discussion of possible causes. In: Sahrhage, D (ed.) Antarctic Ocean and resources variability. Springer-Verlag, Berlin, p. $169-182$

Quetin, L. B., Ross, R. M. (1984). School composition of the Antarctic krill Euphausia superba in the waters of the Antarctic Peninsula in the austral summer of 1982. J. crust. Biol. 4 (Spec. No. 1): 96-106

Robinson, B. J. (1984). Calibration of equipment. Rapp. P.-v. Réun. Cons. int. Explor. Mer 184: 62-67

Rosenberg, J., Hewitt, R. (eds.) (1991). AMLR 1990/91 field season report: objectives, accomplishments, and tentative conclusions. SWFSC Admin. Rep. LJ-91-18. Southwest Fisheries Science Center, La Jolla, CA, p. 1-97

Rosenberg, J., Hewitt, R. (eds.) (1992). AMLR 1991/92 field season report: objectives, accomplishments, and tentative conclusions. SWFSC Admin. Rep. LJ-92-17. Southwest Fisheries Science Center, La Jolla, CA, p. 1-116

Sahrhage, D. (1988). Some indications for environmental and krill resources variability in the Southern Ocean. In: Sahrhage, D. (ed.) Antarctic Ocean and resources variability. Springer-Verlag, Berlin, p. 33-40

SC-CAMLR-IV. (1985). Report of the fourth meeting of the Scientific Committee for the Conservation of Antarctic Marine Living Resources. CCAMLR, Hobart

SC-CAMLR-V. (1986). Report of the fifth meeting of the Scientific Committee for the Conservation of Antarctic Marine Living Resources. CCAMLR, Hobart

SC-CAMLR-X. (1991). Report of the tenth meeting of the Scientific Committee for the Conservation of Antarctic
Marine Living Resources. CCAMLR, Hobart

Sherman, K., Ryan, A. F. (1988). Antarctic marine living resources. Oceanus 31(2): 59-63

Siegel, V. (1986a). Structure and composition of the Antarctic krill stock in the Bransfield Strait (Antarctic Peninsula) during the Second International BIOMASS Experiment (SIBEX). Arch. FischWiss. 37: 51-72

Siegel, V (1986b). Untersuchungen zur Biologie des antarktischen Krill, Euphausia superba, im Bereich der Bransfield Straß̂e und angrenzender Gebiete. Mitt. Inst. Seefisch. Hamburg 38: 1-244

Siegel, V. (1988). A concept of seasonal variation of krill (Euphausia superba) distribution and abundance west of the Antarctic Peninsula. In: Sahrhage, D. (ed.) Antarctic Ocean and resources variability, Springer-Verlag, Berlin, p. $219-230$

Simmonds, E. J., Williamson, N. J., Gerlotto, F., Aglen, A. (1991). Survey design and analysis procedures: a comprehensive review of good practice. Comm. Meet. int. Coun. Explor. Sea 1991/B: 54

Stanton, T. K. (1983). Multiple scattering with applications to fish-echo processing. J. Acoust. Soc. Am. 73: 1164-1169

Stanton, T. K. (1989). Simple approximate formulas for backscattering of sound by spherical and elongated objects. J. Acoust. Soc. Am. 86: 1499-1510

Stein, M. (1986). Variability of water masses and currents off the Antarctic Peninsula during SIBEX. Arch. FischWiss. 37: $25-50$

Wiebe, P. H., Greene, C. H., Stanton, T K., Burczynski, J. (1990). Sound scattering by live zooplankton and micronekton: empirical studies with a dual-beam acoustical system. J. Acoust. Soc. Am. 88: 2346-2360

Witek, Z., Kalinowski, J., Grelowski, A. (1988). Formation of Antarctic krill concentrations in relation to hydrodynamic processes and social behavior. In: Sahrhage, D. (ed.) Antarctic Ocean and resources variability. SpringerVerlag, Berlin, p. 237-244

Manuscript first received: February 9, 1993 Revised version accepted: May 28, 1993 